

\section{Jussi Lankoski*) and Markku Ollikainen**)}

\section{Bioenergy crop production and climate policies:}

\section{A von Thunen model and case of reed canary grass in Finland ${ }^{1}$}

October 30, 2006

*) Agrifood Research Finland, Economic Research, P.O. Box 3, FIN-00411 Helsinki. Finland. E-mail: jussi.lankoski@mtt.fi, and the OECD, Paris (2005-2007).

**) Department of Economics and Management, P.O. Box 27, 00014 University of Helsinki. E-mail: markku.ollikainen@helsinki.fi

\footnotetext{
${ }^{1}$ We thank Stefan Bäckman, Wilfrid Legg and Frank van Tongeren for helpful comments.
} 


\title{
Bioenergy crop production and climate policies: A von Thunen model and case of reed canary grass in Finland
}

\begin{abstract}
We examine bioenergy crop cultivation in a von Thunen framework with homogenous agricultural land and increasing transportation costs by distance. Bioenergy crops can offset emissions from fossil fuels but their cultivation causes nutrient runoff. Increasing transportation costs imply that the fertilizer intensity differs across locations; it also defines the socially and privately optimal extensive margin of bioenergy crop production. If climate benefits are only partially capitalized in the bioenergy crop price, the privately optimal fertilizer application is suboptimal calling for location specific input or output subsidies. A theoretical model is applied to reed canary grass (Phalaris arundinacea L.) cultivation in Finland. Reed canary grass offsets emissions from peat in electricity production. Using oats as an alternative crop and permit price $€ 20 /$ tonne of $\mathrm{CO}_{2}$ emissions as a proxy for the climate benefits, cultivation of reed canary grass is socially optimal at a distance over 100 kilometres from the power plant and still offsets more than 6.5 tonnes per ha of $\mathrm{CO}_{2}$ emissions from peat.
\end{abstract}

Keywords: von Thunen model, climate benefits, bioenergy crops, emission permit market, nutrient runoff

JEL classification: Q18, Q24, Q25 


\section{Introduction}

The agricultural sector is both a source and a sink of greenhouse gases (GHG) (carbon dioxide $\mathrm{CO}_{2}$, methane $\mathrm{CH}_{4}$, and nitrous oxide $\mathrm{N}_{2} \mathrm{O}$ ). The share of agriculture in OECD total national gross emissions in $\mathrm{CO}_{2}$ equivalents is below $10 \%$, but for methane and nitrous oxide agriculture contributes a major share, $40 \%$ and $60 \%$, respectively (OECD 2001). The agricultural sector has the potential for absorbing $\mathrm{CO}_{2}$ emissions through changes in tillage practices, such as adopting no-till, or changes in land use forms, such as conversion of arable land to grassland.

What is more, agriculture has the potential to offset GHG emissions through production of bioenergy from agricultural biomass (feedstocks). Agricultural biomass can be used to produce energy (heat and electricity), and biofuels, for instance, bioethanol and biogas. The recently established European Union Emission Trading Scheme (EU-ETS) has opened new possibilities for the production of bioenergy crops in Europe. Emissions generated using fossil fuels in energy production belong to the EU-ETS, while emissions from renewable energy do not. Because power plants must pay a permit price for each unit of $\mathrm{CO}_{2}$ emitted from fossil fuels, the relative energy prices have changed in favour of renewable energy sources and their use is increasing. ${ }^{2}$

For farmers bioenergy crop cultivation provides an interesting new production alternative and for society bioenergy crops provide potential climate benefits and some other positive environmental effects as well. Given that most bioenergy crops are perennial crops with less tillage and lower fertilizer intensity than in cereals production, nutrient runoff to watercourses could be reduced as well. These positive effects are, however, to some extent offset by the fact that transportation of bioenergy crops causes emissions. Moreover, transportation is costly relative to the value of transported feedstock, which implies that the demand for bioenergy crops and the resulting production provides a local

\footnotetext{
${ }^{2}$ In the Finnish energy sector peat is typically replaced by bioenergy from agriculture or from forestry. Peat is subject to EU-ETS and its profitability has decreased quite dramatically. Many power plants currently use a mixture of peat and reed canary grass. Some power plants use a mixture of wood chips and reed canary grass to hedge against volatile wood chips prices.
} 
solution at best. Hence, an interesting research question is whether the production of bioenergy crops is socially desirable when environmental and economic effects are taken into account - and to what extent?

In this paper we examine the socially and privately optimal production of bioenergy crops. We develop a von Thunen framework, which is well-designed to analyse economic decisions when distance matters. In our model a power plant, locating at the centre of an area, demands bioenergy crops. The arable land around the power plant is homogenous in terms of its productivity. Transportation is costly and effectively reduces profitability of bioenergy crop production when the distance to the power plant increases. Our analysis comprises both $\mathrm{CO}_{2}$ emissions to air and nutrient runoff to waterways. We define the optimal fertilizer intensity in each location. For the given alternative crop, we determine the extensive margin of production; this gives the area that is optimal to allocate to the production of bioenergy crops. Finally, we examine the private incentives of bioenergy crop cultivation and design the first-best instruments to encourage bioenergy cultivation to the socially optimal level.

To assess empirically the private profitability and social returns of bioenergy crop production, we apply our von Thunen model to Finnish agriculture. We consider cultivation of reed canary grass (Phalaris arundinacea L.), which is regarded as the most suitable bioenergy crop for the climatic conditions in northern Scandinavia (Landström et al. 1996). According to Finnish experiments, reed canary grass can be cultivated on almost all soil types (textural classes) but highest yields are obtained on organic soils. In the Finnish climatic and soil conditions reed canary grass produces 6-8 tons of dry mass per hectare for a time period of 10-12 years (Pahkala et al. 2005). The average net calorific heat value is 2.45-3.94 MWh per ton of dry mass (with moisture content of 15$20 \%$ ), yielding a mean energy production of $19.2 \mathrm{MWh}$ per ha at harvest of 6 tonnes per ha.

Our work relates to the previous literature as follows. Earlier studies have mainly been empirical and focused on the potential supply of bioenergy crops. Downing and Graham 
(1996) and Walsh $(1998 ; 2000)$ outline an approach to determine the supply function of bioenergy crops subject to relative prices and government subsidies. Walsh et al. (2003) estimate the bioenergy potential of U.S. agriculture and the required prices of bioenergy to compete on land use with other crops. Larsson (2005) applies a supply function approach to Swedish agriculture. While the above studies neglect the climate effects of bioenergy crops, Faaij et al. (1998) include climate damage when assessing externalities of electricity production from biomass and coal. Börjesson (1999a; 1999b) provide a comprehensive representation of the environmental benefits and economic aspects of energy crop cultivation. Unlike the present paper, these studies do not describe the cultivation of bioenergy crops in detail, nor do they provide a theoretical treatment of the subject.

The rest of the paper is organized as follows. In section 2 we develop the theoretical representation of von Thunen model. The empirical model is developed in section 3 and the results of the analysis are presented in section 4. Conclusions and policy implications are given in section 5 .

\section{Bioenergy production in the von Thunen model}

In this section we develop our theoretical model. The model consists of three basic components: private profits from bioenergy production, nutrient runoff damage and $\mathrm{CO}_{2}$ reduction benefits.

\subsection{The basic framework}

Consider a local power plant that buys a bioenergy crop from the neighbouring fields and uses it to replace some fossil fuel in electricity production. The power plant's ability to pay for the bioenergy crop depends among other things on the energy content of the bioenergy, substitution possibilities between bioenergy and fossil fuel, as well as on the price of emission permits. The power plant pays a gate price $\hat{p}$ for bioenergy. We assume that this price is determined competitively. Moreover, we assume that the net 
price after transportation cost, $p$, decreases in distance, $k$, and is given by $p=\hat{p}-\eta(k)$, where $\eta(k)$ is the (convex) transportation cost with $\eta^{\prime}(k)>0$ and $\eta^{\prime \prime}(k)>0$.

An important question concerning the gate price is whether the climate benefits are actually capitalized in the gate price, or not. Referring to empirical evidence, in Finland the listed gate prices do not include climate benefits but the power plants add to the gate price an emission trading premium, which implies capitalization. However, as we will find in the empirical section, this extra payment does not fully capitalize the climate benefits into the price paid to farmers. We solve the social optimum using the gate price and accounting fully for the social climate benefits. When comparing the social optimum to the private optimum, we account for the emission trading premium and distinguish between partial and full capitalization.

In accordance with the empirical evidence, we assume that the bioenergy crop (such as reed canary grass, or switch grass) is a perennial crop having n-period long rotation age. Producing the bioenergy crop requires an initial investment in the first year. It includes primary tillage (ploughing), seedbed tillage (harrowing), planting, and crop protection. After the first year, an annual fertilizer input, $l$, is applied and the crop provides a positive harvest over $n-1$ years. The energy crop grows according to a concave response function, $Q=f(l)$. We denote the first year's establishment cost by $\bar{C}$ and the real interest rate by $r$. The private profits of a farmer producing bioenergy crop in the relevant locations, $k=1, \ldots, m$, of the neighbourhood of the power plant is given by,

$$
\pi=\sum_{t=2}^{n}\left[(1+r)^{-(t-1)}\left[p f\left(l_{t}\right)-c l_{t}\right]\right]-\bar{C} .
$$

Fertilizer application causes nutrient runoff, $z$, to waterways. It depends on the fertilizer application, so that in each period $t=2, \ldots, n$ we have $z_{t}=g\left(l_{t}\right)$ as the per parcel (location) runoff. We regard the first year's fertilizer application as technologically fixed 
$\left(\bar{z}_{1}=g\left(\bar{l}_{1}\right)\right)$. Let the periodic damage from runoff be $d$. The present value of nutrient damages over the whole rotation period, $D$, can be expressed as,

$$
D=d\left(g\left(\bar{l}_{1}\right)\right)+\sum_{t=2}^{n}(1+r)^{-(t-1)} d\left(g\left(l_{t}\right)\right)
$$

We assume that the damage is increasing and convex $\left(D^{\prime}>0\right.$ and $\left.D^{\prime \prime}>0\right)$.

The bioenergy crop can be used to provide a certain amount of electricity. Let a coefficient $\alpha(0<\alpha<1)$ denote how much electricity is produced from one metric ton of bioenergy. Furthermore, let $\hat{\varepsilon} \quad(0<\hat{\varepsilon}<1)$ denote how much electricity provided by this ton offsets the fossil fuel-based $\mathrm{CO}_{2}$ emission in electricity production. To ease notation we let $\varepsilon=\hat{\varepsilon} \alpha$ to denote the offset of $\mathrm{CO}_{2}$ emissions. Let $b$ denote the periodic social benefits from reduced $\mathrm{CO}_{2}$ emissions. These benefits accrue from the second year onwards, and we denote their present value over the rotation period by $B$

$$
B=\sum_{t=2}^{n} b\left(\varepsilon f\left(l_{t}\right)\right)(1+r)^{-(t-1)}
$$

The climate benefit function is concave in the $\mathrm{CO}_{2}$ offsets $\left(B^{\prime}>0\right.$ and $\left.B^{\prime \prime}<0\right)$.

\subsection{The socially and privately optimal bioenergy crop production}

We start with the socially optimal production and assume that society maximizes the sum of the consumers' and producers' surplus. As we treat the price of bioenergy crop as constant, this amounts to maximizing the sum of equations $(1)-(3)$. Thus, the social welfare function is,

$$
S W=\sum_{t=2}^{n}\left[(1+r)^{-(t-1)}\left[p f\left(l_{t}\right)-c l_{t}-d\left(g\left(l_{t}\right)\right)+b\left(\varepsilon f\left(l_{t}\right)\right)\right]\right]-\bar{C}-d\left(g\left(\bar{l}_{1}\right)\right)
$$


Recall, the establishment of bioenergy crop production is technologically fixed. Thus, the key economic problem of the social planner is to choose fertilizer application over periods $t=2, \ldots, n$ and locations $k=1, \ldots, m$ so as to maximize (4). The first and the second order conditions of the social optimum can be expressed as,

$$
\begin{aligned}
& S W_{l}=p f^{\prime}(l)-c-d^{\prime}(\cdot) g_{l}+b^{\prime}(\cdot) \varepsilon f^{\prime}(l)=0 \\
& S W_{l l}=p f^{\prime \prime}(l)-d^{\prime \prime}(\cdot)\left(g_{l}\right)^{2}-d^{\prime}(\cdot) g_{l l}+b^{\prime \prime}(\cdot)\left(\varepsilon f^{\prime}(l)\right)^{2}+b^{\prime}(\cdot) \varepsilon f^{\prime \prime}(l)<0 .
\end{aligned}
$$

Note first, that equations (5) and (6) hold for any period $t=2, \ldots, n .^{3}$ Thus, the real interest rate does not affect fertilizer intensity, only the present value of the net returns. Therefore, fertilizer intensity remains the same over the rotation period in each location. Hence, the economic interpretation of equation (5) is conventional. Society chooses the level of fertilizer application by equalizing the social marginal benefits to the social marginal costs, that is, $p f^{\prime}(l)+b^{\prime}(\cdot) \varepsilon f^{\prime}(l)=c+d^{\prime}(\cdot) g_{l} \cdot{ }^{4}$ Importantly, fertilizer intensity differs between locations because the net price of the energy crop is decreasing in distance $k$ due to transportation costs, as shown by equation (7):

$$
\frac{d l}{d k}=\frac{\eta^{\prime}(k) f^{\prime}(l)}{S W_{l l}}<0
$$

Assuming all external effects are absent, equation (5) reduces to the privately optimal condition, $p^{*} f^{\prime}(l)=c$, where $p^{*}$ refers to the possibility that the price partially or fully includes the offset benefits via emission trading. Naturally, the privately optimal condition requires that the value of the marginal product of fertilizer use equals the input price. Similarly, fertilizer intensity differs between locations.

\footnotetext{
${ }^{3}$ Given that fertilizer intensity is the same over the whole period, we hereafter drop the time subscripts $t$ from the equations (5) and (6).

${ }^{4}$ Denote the alternative crop by hat and its price by $q$. Then the target function and the first-order condition are $\sum_{t=1}^{n}\left[(1+r)^{-(t-1)}[q \hat{f}(l)-c l-d(\hat{g}(l))]\right.$ and $q \hat{f}^{\prime}(l)-c-d^{\prime}(\cdot) \hat{g}_{l}=0$, respectively. Interpretation is similar as above.
} 
How do the socially and privately optimal solutions relate to each other? It depends on the degree of capitalization of the climate benefits in the price of the bioenergy crop. If no capitalization occurs, the sign of $d^{\prime}(\cdot)\left(g_{l}\right)-b^{\prime}(\cdot) \varepsilon f^{\prime}(l)$ in equation (5) is decisive. If the marginal climate benefits dominate the marginal runoff damages then the socially optimal fertilizer intensity is higher than the privately optimal one; otherwise it is lower. Under full capitalization, private fertilizer intensity is too high, because runoff damage is neglected. Depending on the degree of capitalization, the intermediate cases may entail too high or too low application rates.

The socially and privately optimal extensive margin of bioenergy crop cultivation is defined by the location where the social returns and private profits from bioenergy crop equal those of the alternative crop. Denote the social returns (private profits) from bioenergy crop by $S W^{*}\left(\pi^{0}\right)$ and those of the alternative crop by $\overline{S W}^{*}$ and $\bar{\pi}^{0}$. Then socially and privately optimal extensive margin of bioenergy cultivation is defined by

$$
k^{*}: S W^{*}=\overline{S W}^{*} ; \text { and } k^{0}: \pi^{0}=\bar{\pi}^{0} .
$$

It is easy to demonstrate that the extensive margin of bioenergy crop production depends positively on the price of the bioenergy crop and climate benefits. Interestingly, the extensive margin depends positively also on the input price and nutrient runoff damage, because they decrease the returns of the alternative crop more than those of bioenergy crop. Finally, provided that the alternative crop can be harvested already in the first year $t=1$, a higher interest rate impacts negatively on the extensive margin.

\subsection{First-best design of policy instruments}

As equations (5) - (8) reveal, the socially and privately optimal solutions differ. The difference between the optima is given by $S W_{l}-\pi_{l}=-d^{\prime}(\cdot)\left(g_{l}\right)+b^{\prime}(\cdot) \varepsilon f^{\prime}(l)$. Thus, the privately optimal fertilizer application is either too low or too high depending on the 
marginal social valuation of climate benefits and nutrient runoff damage. Thus, there is scope for intervention to correct for the difference. We examine here two alternative corrective mechanisms. First, the fertilizer intensity can be corrected in each location by a tax or subsidy, depending on the degree of capitalization and the relation of runoff damages to climate benefits. Second, if the capitalization rate is partial and the climate benefits dominate runoff damage, an output subsidy for bioenergy can be provided.

When a tax/subsidy, $h$, is levied on the fertilizer input the farmer's optimal choice becomes $\pi_{l}=p^{*} f^{\prime}(l)-c(1+h)=0$. If an output subsidy is provided for bioenergy, the optimality condition reads as, $\pi_{l}=p^{*}(1+\theta) f^{\prime}(l)-c=0$. Setting these conditions equal to the social optimality condition allows us to solve for the optimal tax/subsidy rates:

$$
\begin{aligned}
& h^{*}(k)=\frac{\left(p^{*}-p\right) f^{\prime}(l)+d^{\prime}(\cdot)\left(g_{l}\right)-b^{\prime}(\cdot) \varepsilon f^{\prime}(l)}{c} \\
& \theta^{*}(k)=\frac{\left(p-p^{*}\right) f^{\prime}(l)+b^{\prime}(\cdot) \varepsilon f^{\prime}(l)-d^{\prime}(\cdot)\left(g_{l}\right)}{p^{*} f^{\prime}(l)} .
\end{aligned}
$$

Under zero capitalization, the price difference in (9a) is zero and we have an input tax or subsidy depending on whether runoff damage or climate benefits dominate. Full capitalization in turn means that the price difference equals the marginal climate benefits and we obtain a tax for excessive fertilization. In the intermediate case, the degree of capitalization affects not only the rate of the tax/subsidy but it may also switch a subsidy to a tax and vice versa. The smaller is the capitalization, the more likely a subsidy is needed to internalize the climate benefits and vice versa.

A similar reasoning holds true for the output subsidy in (9b), but recall, an output subsidy is meaningful only under zero or partial capitalization (where climate benefits dominate). Finally, it is evident from (9a) and (9b) that the subsidy/tax schemes are location-specific, because the optimal fertilizer intensity differs across locations. Thus, differentiated policy instruments are called for in the von Thunen model (the results resemble differentiated policies under heterogeneous land quality, see Lichtenberg 2002, and Lankoski and 
Ollikainen 2003). Furthermore, equations (9a) and (9b) also ensure that the extensive margin becomes optimal (for a similar proof under heterogeneous conditions, see the above references).

It is well known that differentiated policies with precise targeting may entail high transaction costs (see e.g. Vatn 2002 for general discussion). Thus, we complete this section by outlining an alternative second-best policy option for the case where climate benefits dominate nutrient runoff damage and promoting bioenergy production becomes socially optimal.

Suppose that the government pays a lump-sum area payment, $A$, for bioenergy production in each location. Then private profits are given by

$$
\pi=\sum_{t=2}^{n}\left[(1+r)^{-(t-1)}(p f(l)-c l)+A\right]-\bar{C}+A
$$

Obviously, the area payment $A$ does not affect optimal fertilizer intensity. However, it makes bioenergy production more profitable relative to the alternative crop, therefore affecting the extensive margin. If the aim is to expand bioenergy crop production towards the socially optimal level, the government should use an area payment that makes the private restricted profit function equal to that under the alternative exogenous crop at the socially optimal location $k^{*}$. Hence, choosing $A=\bar{\pi}^{0}\left(k^{*}\right)-\pi^{0}\left(k^{*}\right)$ will yield the socially optimal extensive margin. However, as a result the total amount of bioenergy produced still differs from the socially optimal level of production, because the fertilizer intensity has not been corrected to the socially optimal level.

\section{The empirical application of the von Thunen model}

We illustrate our results empirically using data from the Ostrobothnia region, which is located in Western Finland. The Ostrobothnia region has two main power plants in Seinäjoki and Pietarsaari, which have a potential capacity to produce $242 \mathrm{GWh}$ and 310 
GWh of electricity from reed canary grass, respectively. If the average energy yield of reed canary grass is $19.17 \mathrm{MWh}$ per ha (with 6 tonnes/ha yield level), then the above data would mean that 12624 hectares and 16171 hectares of arable land are required to be allocated to reed canary grass cultivation, respectively.

Arable land in the Ostrobothnia region is dominated by three soil types: fine sand $(32.4$ $\%)$, coarse sand $(17.9 \%)$, and organic (including peat) soils $(21.9 \%)$. While all soil types suit reed canary grass cultivation, the yields are highest in organic soils. Oats is the most typical cereal crop in Ostrobothnia, representing $39.6 \%$ (37\%) of total cereal cultivation area in 2004 (2005) (Yearbook of Farm Statistics 2005). Among cereals cultivated in Finland oats is best suited to peat and organic soils. Therefore, we take oats as our alternative crop.

\subsection{Parametric version of the model}

Both reed canary grass and oats are transported by road transportation (truck and trailer unit). ${ }^{5}$ To keep the analysis clear, we assume that the power plant and the oats processing industry are located in the same location. Following Flyktman and Paappanen (2005) we employ the following cubic transportation cost function, $\omega$, for reed canary grass (transported as round bales): $\omega^{1}=\alpha k^{3}-\beta k^{2}+\chi k+\eta$. For oats, the Finnish data suggests a linear transportation cost: $\omega^{2}=\varphi+\not k$. Thus, the net prices of both crops are given by $p=\hat{p}-\omega^{1}$, and $q=\hat{q}-\omega^{2}$, respectively, where hat refers to the prices at the gate of the power plant $(p)$ and the processing firm $(q)$.

We use the following Mitscherlich nitrogen response function for both crops: $y^{i}=\mu^{i}\left(1-\sigma^{i} e^{-v_{i} l_{i}}\right)$, where $y$ is yield per hectare, $l$ is nitrogen use per hectare, and $\mu, \sigma$ and $v$ are parameters. These parameters are estimated for oats by Bäckman et al. (1997). On the basis of Finnish experiments and nitrogen use recommendations for different soil

\footnotetext{
${ }^{5}$ In what follows, the superscript 1 refers to reed canary grass and superscript 2 to oats $(i=1,2)$ and we use subscripts to refer to time.
} 
textural classes (clay, sandy, and organic soils) we calibrate Mitscherlich nitrogen response function for reed canary grass to reflect average yields of reed canary grass obtained with the recommended nitrogen use per ha.

Reed canary grass is a perennial crop, which is planted for a 14 year production rotation, the annual harvests starting from the third year. Fertilizer application is technologically fixed for the first two years. The private profits from reed canary grass cultivation over any location are given by

$$
\pi^{1}=\sum_{t=3}^{n}\left[(1+r)^{-(t-1)}\left(p \mu\left(1-\sigma e^{-v l}\right)-c l-I-K+A\right)\right]-\bar{C}_{1}-\bar{C}_{2}(1+r)^{-1}
$$

In equation (11), $\bar{C}_{1}=E+K+A$ and $\bar{C}_{2}=c \bar{l}_{2}+I+K+A$ comprise the establishment and some other cost items during the first two years, 1 and 2. $E$ is the establishment costs (fuel and labour costs of primary tillage, secondary tillage, and herbicide application, as well as fertilizer, seed and herbicide costs), $I$ denotes the variable costs of cultivation, and $K$ refers to fixed machinery costs. Finally, we denote the annual crop area payment by $A$.

The profits from the alternative crop, oats are given by

$$
\pi^{2}=\sum_{t=1}^{n}\left[(1+r)^{-(t-1)}\left(q \mu\left(1-\sigma e^{-v l}\right)-c l-I-K+A\right)\right] .
$$

The climate benefits from reed canary grass are modelled as offset benefits from emissions of peat in electricity generation. The net calorific heat value is $2.45-3.94 \mathrm{MWh}$ per tonne of dry matter (with the moisture content of $15-20 \%$ ) for reed canary grass and 2.68 MWh per tonne for peat. Using the average heat value for reed canary grass, 3.195 $\mathrm{MWh} / \mathrm{ton}$, the amount of peat needed to produce same amount of energy is approximately 1.19 tonnes. The emission coefficient for peat is $381.6 \mathrm{~kg} \mathrm{CO}_{2} / \mathrm{MWh}$. Thus, one tonne of reed canary grass can reduce $\mathrm{CO}_{2}$ emissions from peat by $1219 \mathrm{~kg} \mathrm{CO}_{2}$ in power production. We use the price of emission allowances as a proxy for the marginal climate 
benefits. In the first trading year (2005), the average allowance price was slightly over $€$ 20/tonne and we use this estimate. Oats does not entail any climate benefits, but for reed canary grass we have,

$$
B=\sum_{t=3}^{14}(1+r)^{-(t-1)}[20 * 1.219 * f(l)]
$$

We describe nitrogen runoff resulting from nitrogen application by the following per hectare runoff function $z_{i}=\phi_{i} e^{-0.7\left[1-0.011_{i}\right]}$. Parameter $\phi_{i}$ calibrates this expression so that it equals the level of nitrogen runoff generated by a nitrogen application rate of 100 kilos per hectare for oats and 60 kilos per hectare for reed canary grass. We set the parameter $\phi_{i}=11 \mathrm{~kg} \mathrm{~N} / \mathrm{ha}$ for oats and $\phi_{i}=6 \mathrm{~kg} \mathrm{~N} / \mathrm{ha}$ for reed canary grass on the basis of Finnish experimental studies (Turtola and Jaakkola 1997, Partala and Turtola 1998). For the social value of nitrogen runoff damage $d$ we use an estimate $€ 1.6$ per reduced $\mathrm{kg}$ of nitrogen provided by Vehkasalo (1999). ${ }^{6}$ Hence, the present value of runoff damage differs between the crops and is defined by

$$
\begin{aligned}
& D^{1}=\sum_{t=1}^{2}(1+r)^{-(t-1)}\left(1.6 * 6 * e^{-0.7[1-0.01 \bar{l}]}\right)+\sum_{t=3}^{14}(1+r)^{-(t-1)}\left(1.6 * 6 * e^{-0.7[1-0.01 l]}\right) \\
& D^{2}=\sum_{t=1}^{14}(1+r)^{-(t-1)}\left(1.6 * 11 * e^{-0.7[1-0.01 l]}\right)
\end{aligned}
$$

Finally, we assume that the social returns of crops include the social benefit of retaining land in farming. We denote the annual benefit by $\psi$, so that the discounted benefits over the rotation period, $\Omega$, are

$$
\Omega=\sum_{t=1}^{n}(1+r)^{-(t-1)} \psi
$$

\footnotetext{
${ }^{6}$ The nitrogen runoff function is based on Simmelsgaard (1991). Details of its calibration to Finnish conditions can be found in Lankoski and Ollikainen (2003).
} 
By assumption, this benefit corresponds to Less Favoured Area (LFA) support in the EU, and is paid annually.

Combining equations (11) - (16), and neglecting the area payment $A$, allows us to express the social welfare function for reed canary grass and oats production as,

$$
\begin{aligned}
& S W^{1}=\pi^{1}-D^{1}+B+\Omega \\
& S W^{2}=\pi^{2}-D^{2}+\Omega
\end{aligned}
$$

These equations will be maximized with respect to fertilizer use to provide the results in section 4 .

\subsection{Production costs, prices and support payments for reed canary grass and oats}

All prices, costs and support payments are calculated as from year 2006 (see Tables 1 and A1). We use data from production cost calculations (ProAgria 2006) for both crops in support region $\mathrm{C} 2$, where Ostrobothnia belongs. Table 1 shows the cost structure for reed canary grass and oats cultivation. Oats is an annual crop and its cost items are annual whereas for reed canary grass cost items are presented separately for establishment (once per rotation), management (12 times per rotation) and rotation ending (once per rotation). To make comparison more transparent the total costs of both crops are annualised present values.

We assume in Table 1 that the cereal farmer owns the basic machinery that is required to cultivate cereals and this same machinery is suitable for establishing reed canary grass as well. Thus, farmer bears the fixed costs of machinery (such as depreciation, interest, insurance) regardless of which crop is cultivated. For the estimation of capital and labour costs we use a standard activity set for field operations: primary tillage (mouldboard ploughing), seedbed tillage (harrowing), planting, and herbicide application. Field operations are conducted annually for oats and once per rotation period for reed canary grass. The capital cost is based on the machinery required for the above field operations 
and machinery expense per hectare (which is measured by depreciation costs). The labour cost is based on estimate of hours/ha for different operations and the farmer's wage rate per hour. We assume that for both crops the farmer uses contractor services for harvesting (which in the case of oats covers both harvest and grain drying).

Table 1. Production costs of reed canary grass and oats, $€ /$ ha (own calculations on the basis of ProAgria 2006).

\begin{tabular}{|c|c|c|c|}
\hline \multicolumn{2}{|c|}{ Oats, $€ /$ ha } & \multicolumn{2}{|c|}{ Reed canary grass, $€ /$ ha } \\
\hline Seed & 42 & $\begin{array}{l}\text { 1. Establishment (once per } \\
\text { rotation) }\end{array}$ & 321 \\
\hline Herbicide & 34 & - $\quad$ Seed & 70 \\
\hline Fuel and lubricant & 31 & $\begin{array}{l}\text { - Fertilizer (1. and } 2 . \\
\text { year) }\end{array}$ & 145 \\
\hline Harvest & 87 & - Herbicide & 21 \\
\hline Grain drying & 42 & - Labour & 85 \\
\hline Labour cost & 130 & $\begin{array}{l}\text { 2. Management (12 times } \\
\text { per rotation) }\end{array}$ & 118 \\
\hline \multirow[t]{7}{*}{$\begin{array}{l}\text { Fixed costs of } \\
\text { machinery }\end{array}$} & 144 & $\begin{array}{l}\text { - Material costs } \\
\text { (plastics and nets) }\end{array}$ & 33 \\
\hline & & - Harvest & 80 \\
\hline & & $\begin{array}{l}\text { - Labour, fuel and } \\
\text { lubricant cost }\end{array}$ & 5 \\
\hline & & $\begin{array}{l}\text { 3. Costs of rotation ending } \\
\text { (once per rotation) }\end{array}$ & 25 \\
\hline & & - Herbicide & 19 \\
\hline & & - Labour & 6 \\
\hline & & $\begin{array}{l}\text { 4. Fixed costs of } \\
\text { machinery }\end{array}$ & 144 \\
\hline $\begin{array}{c}\text { Annualised } \\
\text { total costs }\end{array}$ & 411 & $\begin{array}{l}\text { Annualised } \\
\text { total costs }\end{array}$ & 218 \\
\hline
\end{tabular}

As Table 1 reveals, the annualised total cost difference between the two crops is large. The cost difference is $€ 238$ per ha in favour of reed canary grass. The difference in labour costs is especially remarkable. The rest of the parameter values, including prices and area payments, are reported in Appendix 1, Table A.1. 


\section{Reed canary grass cultivation: optima and policies}

We start by reporting the socially optimal production of reed canary grass and oats, which provide a benchmark for our policy analysis. The results are reported in terms of nitrogen application rate, production, environmental effects and social welfare (SW).

\subsection{The social optimum}

Society chooses for each location the crop that produces the highest social welfare (SW) when environmental effects are accounted for as in equation (8). The socially optimal use of nitrogen, production, environmental effects and the overall social welfare for each location and for both crops are given in Table 2 . $^{7}$

Table 2. Social optimum: fertiliser use, crop production and social welfare under oats and reed canary grass cultivation.

\begin{tabular}{|c|c|c|c|c|c|c|c|c|c|}
\hline \multirow{2}{*}{$\begin{array}{c}\text { Locati } \\
\text { on, } \\
k\end{array}$} & \multicolumn{4}{|c|}{ Reed canary grass } & \multicolumn{4}{c|}{ Oats } \\
\cline { 2 - 10 } & $\begin{array}{c}\text { Nitrogen } \\
\mathrm{kg} / \mathrm{ha}\end{array}$ & $\begin{array}{c}\text { Product } \\
\text { ion, } \\
\mathrm{kg} / \mathrm{ha}\end{array}$ & $\begin{array}{c}\mathrm{N}- \\
\text { runoff, } \\
\mathrm{kg} / \mathrm{ha}\end{array}$ & $\begin{array}{c}\mathrm{CO}_{2}- \\
\text { reducti } \\
\text { on } \\
\text { tonnes/ } \\
\mathrm{ha}\end{array}$ & $\begin{array}{c}\mathrm{SW}, \\
\text { f/ha }\end{array}$ & $\begin{array}{c}\text { Nitrog } \\
\text { en use, } \\
\mathrm{kg} / \mathrm{ha}\end{array}$ & $\begin{array}{c}\text { Produc } \\
\text { tion, } \\
\mathrm{kg} / \mathrm{ha}\end{array}$ & $\begin{array}{c}\mathrm{N}- \\
\text { runoff, } \\
\mathrm{kg} / \mathrm{ha}\end{array}$ & $\begin{array}{c}\mathrm{SW} \\
\text { €/ha }\end{array}$ \\
\hline 0 & 67.4 & 6216 & 6.5 & 7.58 & 108.9 & 75.8 & 3087 & 9.29 & 7.2 \\
\hline 10 & 59.8 & 5985 & 6.0 & 7.30 & 80.8 & 74.9 & 3076 & 9.23 & 2.3 \\
\hline 20 & 57.8 & 5918 & 5.9 & 7.22 & 74.2 & 74.7 & 3074 & 9.21 & 1.0 \\
\hline 30 & 55.9 & 5849 & 5.7 & 7.13 & 68.0 & 74.4 & 3071 & 9.20 & -0.2 \\
\hline 40 & 53.9 & 5777 & 5.6 & 7.04 & 62.2 & 74.2 & 3068 & 9.18 & -1.5 \\
\hline 50 & 51.9 & 5703 & 5.5 & 6.95 & 56.7 & 74.0 & 3065 & 9.17 & -2.7 \\
\hline 60 & 49.9 & 5625 & 5.3 & 6.86 & 51.5 & 73.7 & 3062 & 9.15 & -3.9 \\
\hline 70 & 47.9 & 5544 & 5.2 & 6.76 & 46.5 & 73.5 & 3060 & 9.14 & -5.2 \\
\hline 80 & 45.9 & 5460 & 5.1 & 6.66 & 41.8 & 73.3 & 3057 & 9.12 & -6.4 \\
\hline 90 & 43.9 & 5373 & 5.0 & 6.55 & 37.3 & 73.0 & 3054 & 9.11 & -7.6 \\
\hline 100 & 42.0 & 5282 & 4.9 & 6.44 & 33.0 & 72.8 & 3051 & 9.09 & -8.9 \\
\hline
\end{tabular}

\footnotetext{
${ }^{7} \mathrm{We}$ report all results in $10 \mathrm{~km}$ grids in order to make reporting of results less tedious. However, results are calculated in $1 \mathrm{~km}$ grid.
} 
Table 2 shows that the socially optimal nitrogen application for both crops varies and decreases with respect to the distance to the power plant (reed canary grass) or processing plant (oats). Oats has higher nitrogen intensity than reed canary grass in every location. Due to the increasing transportation costs, the nitrogen intensity decreases more steeply for reed canary grass than for oats. The $\mathrm{CO}_{2}$ tonnes/ha replaced by reed canary grass decreases with decreasing yields. Still, at a distance of $100 \mathrm{~km}$, reed canary grass can offset almost 6.5 tonnes of the $\mathrm{CO}_{2}$ from the burning of peat. Due to lower nitrogen intensity and smaller propensity to runoff, reed canary grass has a lower per ha nitrogen runoff than oats in all locations, the difference being on average about $40 \%$.

Table 2 reports the environmental effects in physical terms. How do they relate in terms of social valuation of climate benefits and runoff damages? The climate benefits are obtained by multiplying the $\mathrm{CO}_{2}$ offsets in each location by the allowance price 20 $€ /$ tonne. Multiplying, the nitrogen runoff $\mathrm{kg} / \mathrm{ha}$ by the damage estimate $€ 1.6$ per $\mathrm{kg}$ of $\mathrm{N}$ produces the runoff damages in each location. For example, in location 10 we find that climate benefits are $€ 146$ /ha, whereas runoff damage is $€ 9.6 /$ ha. For all locations the climate benefits clearly dominate nitrogen runoff damage. Because of the climate benefits reed canary grass produces higher social returns than oats in every location. Oats produces positive social returns only up to location 20 and after that the returns become negative.

\subsection{Comparison of the social optimum and the current policy regime}

We next compare the social optimum with the current policy regime to see what kind of incentives current policy provides for bioenergy crop production. Recall that, the European Union pays a lump-sum energy crop payment ( $€ 45 / \mathrm{ha}$ ). This area payment together with the Common Agricultural Policy and national policy instruments determine the competitiveness of reed canary grass production relative to oats. We condense our findings in Figures 1 and 2. Details are presented in Appendix 2, Table A.3, which shows e.g. the privately optimal fertilization rate under the current policy regime. 
In Figure 1, RCG denotes reed canary grass, SO denotes the socially optimal solution and $\mathrm{CR}$ refers to current policy regime. The graphs in Figure 1 indicate the optimal nitrogen intensity as a function of distance for the social optimum and current policy.

Figure 1. Socially (SO) and privately optimal (CR) nitrogen use as a function of distance for reed canary grass $(R C G)$ and oats.

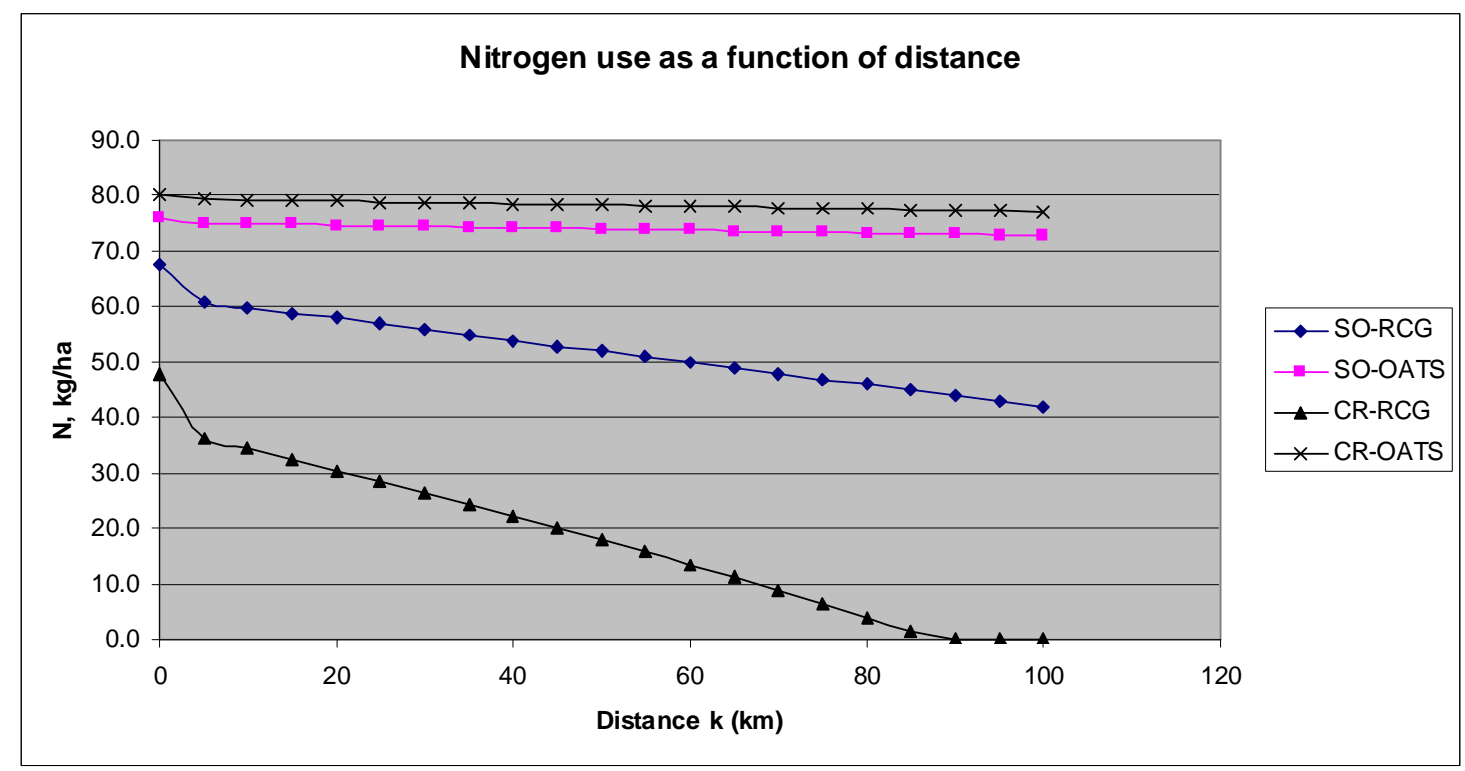

From Figure 1, fertilizer intensity under current policy in oats cultivation is higher than the socially optimal application. For reed canary grass, current policy implies suboptimal and deeply decreasing nitrogen intensity with respect to distance. Therefore, from location 80 onwards the nitrogen intensity becomes so small that yield decreases below the critical yield level of $3000 \mathrm{~kg} / \mathrm{ha}$ required for the energy crop payment. Thus, no energy crop payment is paid for location $80 \mathrm{~km}$ and thereafter (see Figure 2). The optimal nitrogen application rate becomes zero in location $90 \mathrm{~km}$.

Figure 2 shows the annualized net present value profits (€/ha) for both crops in the current policy regime. Reed canary grass 1 describes the current level of support payments, whereas reed canary grass 2 assumes the same level of support payments for 
both crops (the energy crop payment is $€ 45 /$ ha and the difference in regional payments is $€ 5 /$ ha and those are removed from reed canary grass).

Figure 2. Profits (€/ha) for oats and reed canary grass as a function of distance $k$ under current policy regime.

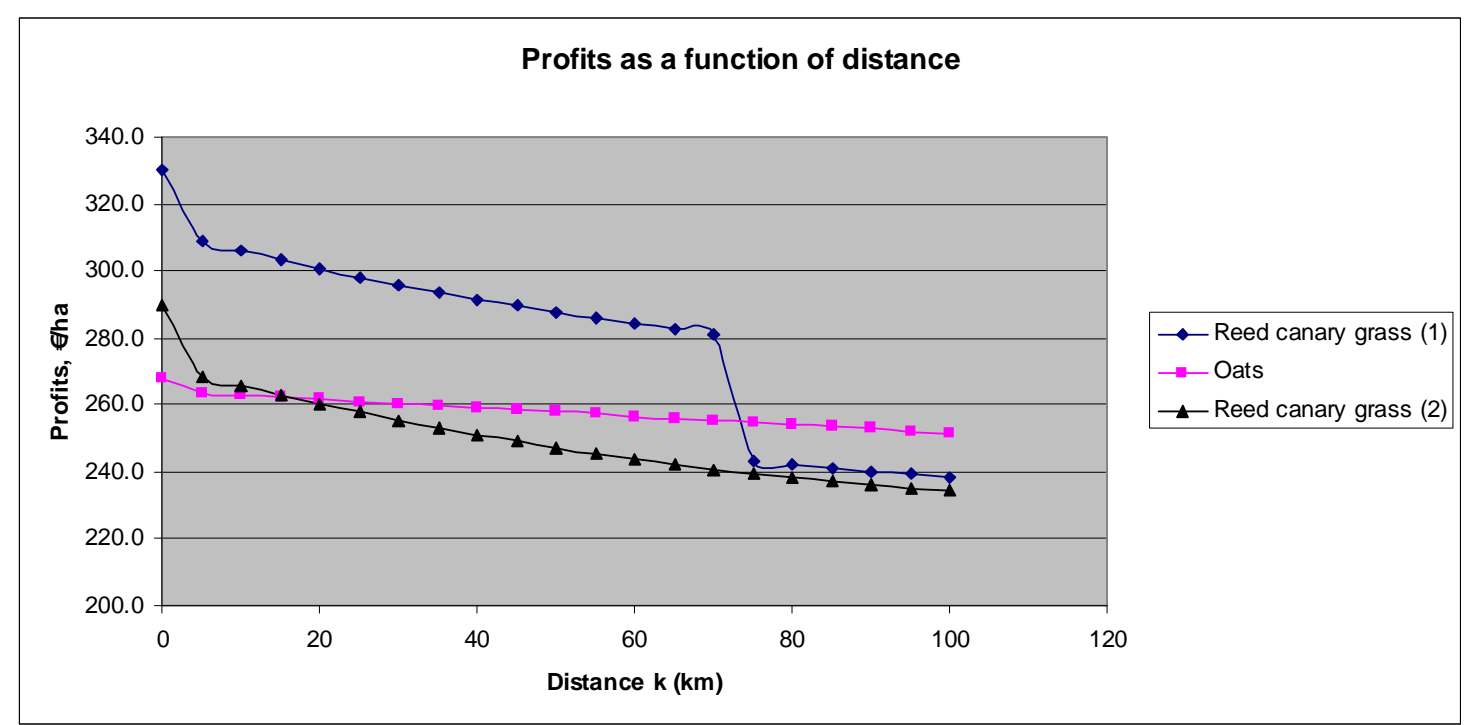

Figure 2 shows two crossing points. Under the same area payments, oats cultivation becomes more profitable from location 20 onwards, as the reed canary grass 2 line cuts oats from above. Thus, using 20 kilometres as a ray of the circle, the total profitable land area for reed canary grass would be $1256 \mathrm{~km}^{2}$ (125 $600 \mathrm{ha}$ ). In the Ostrobothnia region, the total arable land area was 243800 hectares in year 2005 making $20 \%$ of total land area (Yearbook of Farm Statistics 2005). Consequently, using 20\% as a share of arable land in the total land area, and the $20 \mathrm{~km}$ wide profitable distance for reed canary grass, would cover 25120 ha of arable land, accounting for $10.3 \%$ of the total arable land in the region.

In the case of reed canary grass 1 , the energy crop area payment as well as slightly higher regional area payment makes reed canary grass more profitable up to location 80 . From location 80 onwards reed canary grass yield decreases below the critical yield level required for the energy crop payment and thus there is significant drop in its profitability 
as shown in Figure 2. Thus, we find that under the current policy regime the profitability of reed canary grass is mainly driven by support payments (totalling $€ 591 /$ ha), which are $€ 50 /$ ha higher than the corresponding support payments for oats (totalling $€ 541 / \mathrm{ha}$ ).

We, finally, compare the environmental effects associated with the social optimum and the current policy regime in Table 3.

Table 3. Environmental effects: social optimum (SO) and current policy regime (CR).

\begin{tabular}{|c|c|c|c|c|c|c|}
\hline \multirow{2}{*}{$\begin{array}{c}\text { Loca- } \\
\text { tion, } k\end{array}$} & \multicolumn{2}{|c|}{$\begin{array}{c}\text { Reed canary grass } \\
\text { N-runoff, kg/ha }\end{array}$} & \multicolumn{2}{c|}{$\begin{array}{c}\text { Reed canary grass } \\
\mathbf{C O}_{2} \text { reduction, tons/ha }\end{array}$} & \multicolumn{2}{c|}{$\begin{array}{c}\text { Oats } \\
\text { N-runoff, kg/ha }\end{array}$} \\
\cline { 2 - 7 } & $\boldsymbol{S O}$ & $\boldsymbol{C R}$ & $\boldsymbol{S O}$ & $\boldsymbol{C R}$ & $\boldsymbol{S O}$ & $\boldsymbol{C R}$ \\
\hline 0 & 6.5 & 5.2 & 7.58 & 6.76 & 9.29 & 9.57 \\
\hline 10 & 6.0 & 4.4 & 7.30 & 5.97 & 9.23 & 9.51 \\
\hline 20 & 5.9 & 4.2 & 7.22 & 5.70 & 9.21 & 9.50 \\
\hline 30 & 5.7 & 4.1 & 7.13 & 5.40 & 9.20 & 9.48 \\
\hline 40 & 5.6 & 3.9 & 7.04 & 5.07 & 9.18 & 9.46 \\
\hline 50 & 5.5 & 3.7 & 6.95 & 4.69 & 9.17 & 9.45 \\
\hline 60 & 5.3 & 3.5 & 6.86 & 4.27 & 9.15 & 9.43 \\
\hline 70 & 5.2 & 3.3 & 6.76 & 3.78 & 9.14 & 9.42 \\
\hline 80 & 5.1 & 3.1 & 6.66 & 3.21 & 9.12 & 9.40 \\
\hline 90 & 5.0 & 3.0 & 6.55 & 2.73 & 9.11 & 9.38 \\
\hline 100 & 4.9 & 3.0 & 6.44 & 2.73 & 9.09 & 9.37 \\
\hline
\end{tabular}

For reed canary grass the social optimum implies higher nutrient runoff and $\mathrm{CO}_{2}$ replacement than under the current policy, because current policy fails to account for the climate benefits of reed canary grass cultivation. For oats we have the opposite situation: the current policy leads to higher nitrogen intensity and nitrogen runoff than the social optimum. ${ }^{8}$

\footnotetext{
${ }^{8}$ We did not include external costs from fuel consumption in cultivation and transportation of the crops. Oats cultivation consumes 150 liters of fuel per ha annually and cultivation of reed canary grass consumes 56 liters per ha. This strengthens the case for reed canary grass. However, oats has clear advantage as regards to fuel consumption in transportation. Using the average distance of 50 kilometres and socially optimal levels of production for both crops we estimate that for the required transportation capacity the fuel consumption is 7.7 liters per ha for reed canary grass and 1.9 liters per ha for oats. Hence, the overall difference is 88.2 liters in favor of reed canary grass.
} 


\subsection{Optimal policy instruments}

The theoretical model established the need for government intervention to correct for negative and positive externalities related to runoff damage and climate benefits. The sign and the level of the instruments depend on the degree of capitalization of climate benefits in the price of reed canary grass. Therefore, we derive the first-best policy instruments assuming zero and partial capitalization. For the latter we use the current Finnish practice where the ETS allowance premium paid over the ordinary gate prices is on average $€ 7 /$ tonne at the gate ${ }^{9}$. The location-specific instruments, the nitrogen and output subsidies, are reported in Table 4 for reed canary grass under zero (the first figure) and partial capitalization (the second figure).

Table 4 confirms the theoretical finding that the optimal instrument rates differ over the various locations under both zero and partial capitalization. In line with the theoretical analysis, the optimal rates of instruments are much lower under partial than zero capitalization. As expected, the optimal nitrogen tax on oats varies little and decreases only slightly over the various locations. The optimal output subsidy rate increases in distance and shows a rather dramatic (considerable) increase over the various locations in the case of zero (partial) capitalization. While the rate of subsidy for the nitrogen input almost doubles over the distance of 100 kilometres, the output subsidy increases by a factor of nine (two), although the increase in the absolute quantity is not as big as the unit is $\mathrm{kg}$.

\footnotetext{
9 Assume that the listed gate price reflects the true marginal costs of production. Then the estimate of the gate price with full capitalization of climate benefits can be developed as follows. Solve first the social optimum in the presence of climate benefits but in the absence of nutrient runoff. Define then the gate price that makes private profits (in the absence of instruments) equal to the social welfare. This produces a gate price $€ 45.4$ /tonne.
} 
Table 4. First-best policy instruments under zero and partial capitalisation of climate benefits.

\begin{tabular}{|c|c|c|c|}
\hline \multirow{2}{*}{$\begin{array}{c}\text { Location, } \\
k\end{array}$} & \multicolumn{2}{|c|}{ Reed canary grass } & \multirow{2}{*}{$\begin{array}{c}\text { Oats } \\
\text { Nitrogen } \operatorname{tax} \tau, \\
\% \text { and }(€ / \mathrm{kg})\end{array}$} \\
\hline & $\begin{array}{c}\text { Nitrogen subsidy } \boldsymbol{h}, \\
\quad \% \text { and }(€ / \mathrm{kg})\end{array}$ & $\begin{array}{c}\text { Output subsidy } \boldsymbol{\theta} \\
\% \text { and }(€ / \mathrm{kg})\end{array}$ & \\
\hline 0 & $49(0.567) \quad 44(0.51)$ & $96(0.0201) 79(0.0181)$ & $\mathbf{8 . 9 7}(0.1040)$ \\
\hline 10 & $\begin{array}{ll}\mathbf{5 9}(0.688) & \mathbf{4 1}(0.47)\end{array}$ & $146(0.0210) \quad 68(0.0144)$ & $8.91(0.1033)$ \\
\hline 20 & $\mathbf{6 2}(0.723) \quad 41(0.48)$ & $166(0.0212) 70(0.0140)$ & $\mathbf{8 . 8 9}(0.1032)$ \\
\hline 30 & $\mathbf{6 5}(0.759) \quad \mathbf{4 5}(0.52)$ & $189(0.0214) 82(0.0147)$ & $8.88(0.1030)$ \\
\hline 40 & $\mathbf{6 9}(0.795) \quad 46(0.53)$ & $218(0.0216) 85(0.0145)$ & $\mathbf{8 . 8 7}(0.1028)$ \\
\hline 50 & $\mathbf{7 2}(0.834) \quad \mathbf{5 0}(0.58)$ & $256(0.0217) \mathbf{1 0 2}(0.0152)$ & $\mathbf{8 . 8 5}(0.1027)$ \\
\hline 60 & $\mathbf{7 5}(0.873) \quad 52(0.60)$ & $\mathbf{3 0 4}(0.0219) \mathbf{1 0 8}(0.0151)$ & $\mathbf{8 . 8 4}(0.1025)$ \\
\hline 70 & $\mathbf{7 9}(0.915) \quad \mathbf{5 4}(0.62)$ & $\mathbf{3 7 4}(0.0220) \mathbf{1 1 5}(0.0149)$ & $8.82(0.1023)$ \\
\hline 80 & $\mathbf{8 3}(0.957) \quad \mathbf{5 5}(0.64)$ & $472(0.0222) \quad 124(0.0149)$ & $\mathbf{8 . 8 1}(0.1022)$ \\
\hline 90 & $\mathbf{8 6}(0.999) \quad \mathbf{5 8}(0.67)$ & $\mathbf{6 2 0}(0.0223) \mathbf{1 3 6}(0.0149)$ & $8.79(0.1020)$ \\
\hline 100 & $90(1.048) \quad 64(0.74)$ & $\mathbf{9 3 5}(0.0224) \mathbf{1 7 6}(0.0158)$ & $8.78(0.1018)$ \\
\hline
\end{tabular}

Thus, in comparison to the input subsidy, a high level of output subsidy is required to produce the social optimum. This becomes more evident once the required government budget outlays for input subsidy and output subsidy are calculated. While the budgetary cost burden of the input subsidy for nitrogen is on average $€ 42.6 /$ ha (range $38.2-44.0$ ), the output subsidy costs almost three times as much, on average $€ 123.1$ /ha (range 118.5 - 125.5) under zero capitalization. The corresponding figures under the partial capitalization are $€ 29.8$ /ha (range 27.6 - 34.4) for the input subsidy and $€ 86.4$ /ha (range $80.1-112.3$ ) for the output subsidy. Thus, the required government budget outlays for the input subsidy is on average only $34.7 \%$ (34.5\%) of the required output subsidy under zero (partial) capitalization.

The reason for the difference in instruments lies in the way these instruments work. The input subsidy is targeted directly to nitrogen application by decreasing the effective input 
price. The output subsidy works through increasing the value of the marginal product of nitrogen, which is decreasing in fertilizer use. Due to the decreasing marginal productivity of fertilizer, a change in the input price changes nitrogen application more than the corresponding output price change. Thus, under zero and partial capitalization we obtain an interesting and unconventional result: in contrast with the commonly expressed recommendation not to promote the application of fertilizers, we find that a fertilizer subsidy is a superior instrument in promoting bioenergy crop production.

\subsection{Sensitivity analysis}

We performed a sensitivity analysis to examine how the key parameters affect social returns of reed canary grass cultivation. A part of this analysis was to examine how robust the findings are with respect to the chosen alternative crop. Therefore, we chose green set-aside to serve as the alternative crop for reed canary grass.

The social returns for green set aside were calculated using the following items that are the same over all locations. The social value of retaining land in agriculture is the same as before ( $€ 233 /$ ha), the annualised cost of green set aside establishment and management are $€ 20.5 /$ ha, the fixed costs of machinery are $€ 144 /$ ha and nitrogen runoff damage from green set aside is $€ 8 / \mathrm{ha}$. This totals $€ 48$.8/ha as the present value net social return for green set aside. In comparison to baseline results (Table 2) these social returns are higher than those of oats in every location; they also exceed the returns of reed canary grass from location 70 onwards.

To see how alternative values for climate benefits (B) affect the social returns of reed canary grass, we used $€ 10$ /ton and $€ 30$ /ton as alternative permit prices (these values are very close to the lowest and highest values of permit prices during year 2005). The effects are shown in Figure 3 (for details see Table A2.). 
Figure 3. Social welfare ( $S W, € / h a)$ of reed canary grass under alternative values of climate benefits $(B)$ in comparison to green set aside with fixed social returns.

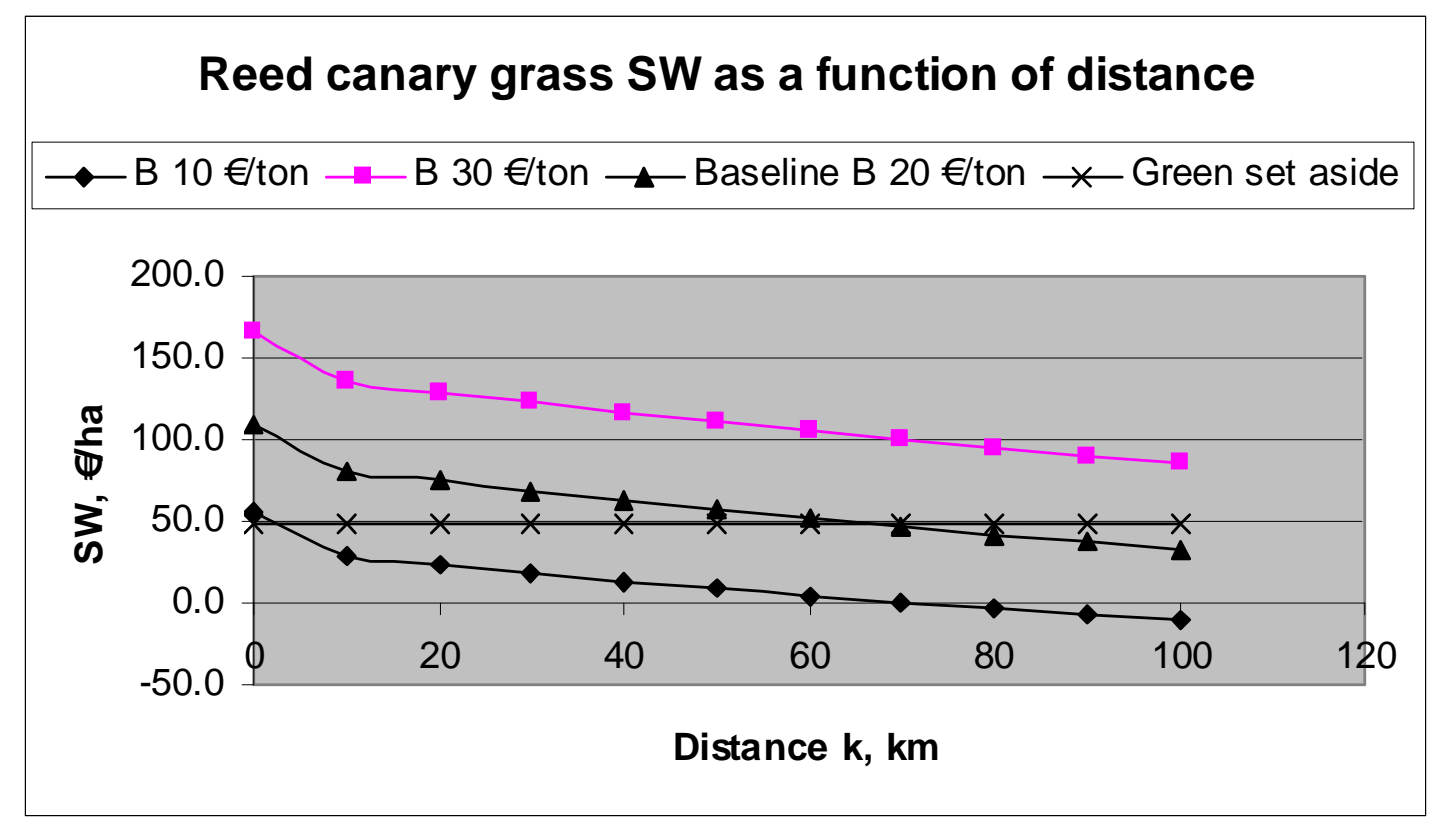

In Figure 3, the baseline case ( $€ 20 /$ ton) has the switching point in location $70 \mathrm{~km}$ for reed canary grass when green set aside is the alternative crop. For a low estimate of climate benefits ( $€ 10 /$ ton), the extensive margin is reduced to $10 \mathrm{~km}$. If climate benefits are high ( $€ 30 /$ ton), the extensive margin shifts outwards, much beyond 100 kilometres.

We condense the rest of the sensitivity analysis in Figure 4, which represents the effects of transportation costs and nutrient runoff damage. Given that a cheaper transportation technology is under intensive investigation, we decrease the transportation costs by $20 \%$. For the marginal nutrient runoff damage, we apply a 50\% higher estimate, which is sometimes reported in Finnish studies. A higher runoff damage estimate is linked to our baseline case ( $€ 20 /$ ton $)$ and to a lower climate benefit estimate ( $€ 10 /$ ton). Note that a higher runoff damage estimate also affects the social welfare performance of green set aside, so that fixed social returns are reduced to $€ 45.6$ per ha. 
Figure 4. Social welfare ( $S W, € / h a)$ of reed canary grass under reduced transportation costs and higher nutrient runoff damage under two alternative values of climate benefits in comparison to green set aside with fixed social returns.

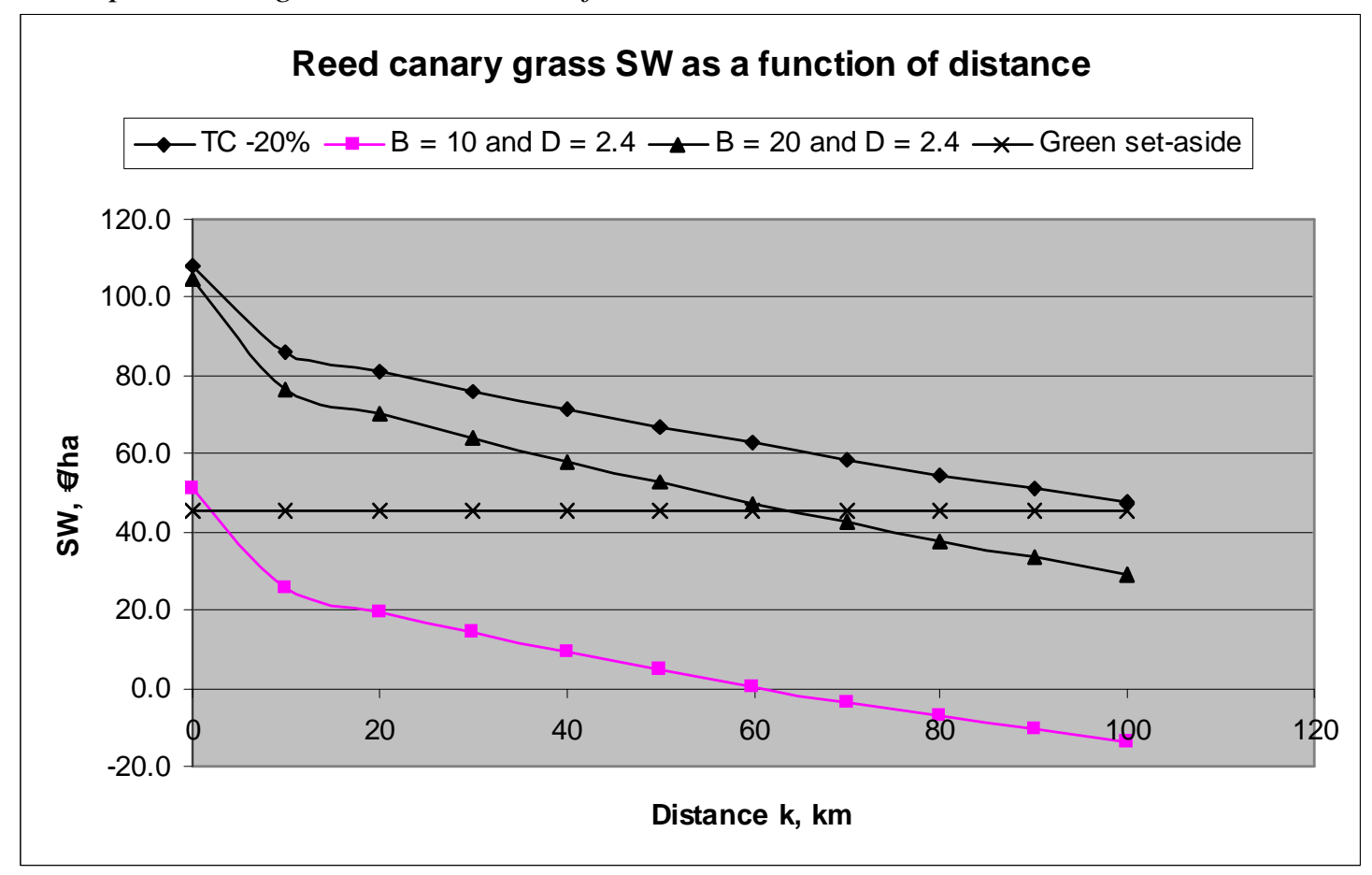

Figure 4 shows that lower transportation costs increase returns to reed canary grass, so that the switching point is moved from $70 \mathrm{~km}$ to slightly over $100 \mathrm{~km}$. A combination of high runoff damage estimate and low climate benefit estimate make reed canary grass an inferior option relative to green set aside as from location $10 \mathrm{~km}$. In comparison to the baseline, a higher runoff damage estimate does not greatly change the relative social profitability of reed canary grass and green set aside since the higher runoff damage estimate affects both land use forms.

\section{Conclusions and policy implications}

The European Union's programmes for promoting the use of renewable energy resources and the introduction of the European Union Emission Trading Scheme (EU-ETS) have increased interest in bioenergy crop cultivation. Bioenergy crops can offset fossil fuels in electricity production and thereby bring climate benefits to society. This paper examined the social returns of bioenergy crop cultivation in a von Thunen framework, when the 
climate benefits are taken explicitly into account. We assumed that agricultural land is homogenous but transportation costs increase with respect to distance. Although offsetting emissions from fossil fuels in electricity production, the cultivation of bioenergy crops causes nutrient runoff to waterways.

We demonstrated that increasing transportation costs determine differing fertilizer application intensities in each location and the extensive margin of production in both the social and private optima. Provided climate benefits are only partially priced by the market, the privately optimal fertilizer application rate is lower than the socially optimal rate across all locations. Under full capitalization the privately optimal fertilizer application is higher than the socially optimal rate because of runoff damages. Thus, differentiated, location-specific policy instruments are needed - input or output subsidies in the former case, and an input tax in the latter case.

The model was applied to the cultivation of reed canary grass in Finnish agriculture, where reed canary grass offsets $\mathrm{CO}_{2}$ emissions from peat in electricity production. The climate benefits were valued by the permit price in the EU-ETS. Using oats as an alternative crop, we demonstrated that cultivation of reed canary grass is socially optimal at a distance greater than 100 kilometres from the power plant and can replace more than 6.5 tonnes of $\mathrm{CO}_{2}$ emissions from peat if climate benefits are valued at $€ 20$ /ton. However, it reduces to 70 kilometres if green set-aside is the alternative land-use form.

Our analysis shows that promoting energy crop cultivation is socially optimal when climate benefits dominate runoff damages and the market only partially prices climate benefits, which empirically holds for reed canary grass in Finland. An input subsidy on fertilizer application turned out to be a preferable policy instrument compared to an output subsidy, because it directly targets the privately suboptimal fertilizer application rate. Moreover, we found that current agricultural policies do not provide the best incentives to encourage bioenergy crop cultivation. Thus, a reform that promotes energy crop cultivation is needed. A good second-best choice is to increase the area payment (which is a part of CAP-policy) designed specifically to energy crops. By using an area 
payment any target area for bioenergy crop production can be achieved, although fertilizer application rates will still differ from the socially optimal rates.

Our analysis relied on the assumption of competitive markets for bioenergy crop. Due to steeply increasing transportation costs the local power plants may, however, act like local monopsonists. On the basis of economic theory we know that they would equalize the marginal buyer cost with the value of the marginal product from the energy crop. This would lead to a market distortion with too low demand for bioenergy crop. It would be an interesting future research topic to examine to whether and to what extent this kind of distortion takes place. Another topic for future work is to focus closely on the social life cycle costs and benefits of using bioenergy crops to provide electricity and heat. 


\section{References}

Bäckman, S.T., Vermeulen, S. and Taavitsainen, V.-M. 1997. Long-term fertilizer field trials: comparison of three mathematical response models. Agricultural and Food Science in Finland 6: 151-160.

Börjesson, P. 1999a. Environmental effects of energy crop cultivation in Sweden - I: Identification and quantification. Biomass and Bioenergy 16, 137-154.

Börjesson, P. 1999b. Environmental effects of energy crop cultivation in Sweden - II: Economic valuation. Biomass and Bioenergy 16, 155-170.

Downing M and R. Graham 1996. The potential supply and cost of biomass from energy crops in the Tennessee Valley Authority region. Biomass and Bioenergy 11, 283-303.

Faaij A., B. Meuleman, W. Turkenburg, A. van Wijk, A. Bauen, F. Rosillo-Calle and D. Hall 1998. Externalities of biomass based electricity production compared with power generation from coal in the Netherlands. Biomass and Bioenergy 14, 125-147.

Flyktman, M. and Paappanen, T. 2005. Ruokohelven käyttökapasiteetti selvitys. Tutkimusselostus PRO2105/05. VTT Prosessit.

Landstrom, S., Lomakka, L., and Anderson, S. 1996. Harvest in spring improves yield and quality of reed canary grass as a bioenergy crop. Biomass \& Bioenergy 11(4): 333341.

Larsson, S. 2005. Supply curves of reed canary grass (Phalaris arundinacea L.) in Västerbotten Counby, northern Sweden, under different EU subsidy schemes. Biomass and Bioenergy 30, 28-37.

Lankoski J. and M. Ollikainen 2003. Agri-Environmental Externalities: A framework for designing targeted policies. European Review of Agricultural Economics 30, 51-75.

Lichtenberg, E. 2002. Agriculture and the environment. In B. Gardner and G. Rausser (eds.), Handbook of Agricultural Economics. Vol 2A: Agriculture and its linkages. Amsterdam: North Holland. pp. 1249 - 1313.

OECD 2001. Environmental indicators for agriculture. Volume 3: Methods and results. 409 pages. OECD, Paris.

Pahkala K., M. Isolahti, A. Partala, A. Suokannas, A-M. Kirkkari, M. Peltonen, M. Sahramaa, T. Lindh, T. Paappanen, E. Kallio and M. Flyktman 2005. Ruokohelven viljely ja korjuu energian tuotantoa varten. 2. korjattu painos. Maa- ja elintarviketalous 1. MTT: Jokioinen. 31 s. ISSN 1458-5073. ISBN 951-729-942-7. In Finnish. Available in web page: http://www.mtt.fi/met/pdf/metlb.pdf 
Partala, A. and Turtola, E. 1998. Nutrient leaching from a peat soil under reed canary grass and timothy ley. Nordisk jordbruksforskning 80(1998):2, p. 52.

ProAgria 2006. Crop budgets and production cost calculations.

Simmelsgaard, S. 1991. Estimation of nitrogen leakage functions - Nitrogen leakage as a function of nitrogen applications for different crops on sand and clay soils. In: Rude, S. (ed.). Nitrogen fertilizers in Danish Agriculture - present and future application and leaching, Institute of Agricultural Economics Report 62 (in Danish: Kvaelstofgödning i landbruget - behov og udvasking nu og I fremtiden). English summary. Copenhagen.p135-150.

Turtola, E. and Jaakkola, A. 1987. Viljelykasvin vaikutus ravinteiden huuhtoutumiseen savimaasta Jokioisten huuhtoutumiskentällä v. 1983-1986. (in Finnish). Maatalouden tutkimuskeskus. Tiedote 22/87. Jokioinen. 33 p.

Vatn, A. (2002). Multifunctional agriculture: some consequences for international trade regimes. European Review of Agricultural Economics 29(3): 309-327.

Vehkasalo, V. 1999. Ympäristötuen yhteiskunnallinen kannattavuus (Abstract: Social profitability of the Finnish agri-environmental programme) pp. 42-77. In: Maatalouden ympäristöohjelma 1995-1999:n taloudellinen analyysi. Agricultural Economics Research Institute, Publications 90. Finland.

Walsh, M. 1998. U.S. bioenergy crop economic analyses: status and needs. Biomass and Bioenergy 14, 341-350.

Walsh, M. 2000. Method to estimate bionergy crop feedstock supply curves. Biomass and Energy 18, 283-289.

Walsh M., D. de la Torre, H. Shapouri, S. Slinksky 2003. Bioenergy Crop Production in the United States. Environmental and Resource Economics 24, 313-333.

Yearbook of Farm Statistics 2005. Information Centre of the Ministry of Agriculture and Forestry. 268 pages. Helsinki, Finland. 


\section{Appendix 1.}

Table A.1 Parameter values in the numerical application.

\begin{tabular}{|c|c|c|}
\hline Parameter & Symbol & Value \\
\hline Gate price of reed canary grass & $\mathrm{p}$ & $€ 0.021 / \mathrm{kg}$ \\
\hline Gate price of oats & $\mathrm{q}$ & $€ 0.107 / \mathrm{kg}$ \\
\hline Price of nitrogen fertilizer & $\mathrm{c}$ & $€ 1.16 / \mathrm{kg}$ \\
\hline \multicolumn{3}{|l|}{ Transportation costs: } \\
\hline \multirow[t]{4}{*}{ Reed canary grass } & $\eta$ & 1.55 \\
\hline & $\chi$ & 0.0538 \\
\hline & $\beta$ & 0.00014 \\
\hline & $\alpha$ & 0.000000356 \\
\hline \multirow[t]{2}{*}{ Oats } & $\varphi$ & 1.5 \\
\hline & $\gamma$ & 0.05 \\
\hline \multirow[t]{6}{*}{ Mitscherlich nitrogen response function } & $\mu_{1}$ & 7650 \\
\hline & $\mu_{2}$ & 3670 \\
\hline & $\sigma_{1}$ & 0.7075 \\
\hline & $\sigma_{2}$ & 0.7075 \\
\hline & $v_{1}$ & 0.0197 \\
\hline & $v_{2}$ & 0.0197 \\
\hline Area payments: & A & $€ / \mathrm{ha}$ \\
\hline CAP (same for both crops) & & 161 \\
\hline LFA (same) & & 233 \\
\hline Agri-environmental payment (same) & & 117 \\
\hline \multicolumn{3}{|l|}{ Regional area payment } \\
\hline Reed canary grass & & 35 \\
\hline Oats & & 30 \\
\hline Energy crop payment (only for Crop 1) & & 45 \\
\hline \multirow[t]{2}{*}{ Nitrogen leakage at average nitrogen use } & $\phi_{1}$ & $6 \mathrm{~kg} / \mathrm{ha}$ \\
\hline & $\phi_{2}$ & $11 \mathrm{~kg} / \mathrm{ha}$ \\
\hline Capital cost & $\mathrm{K}$ & $€ 144 / \mathrm{ha}$ \\
\hline $\begin{array}{l}\text { Social benefit of retaining land in agriculture } \\
\text { (same for both crops) }\end{array}$ & $\Psi$ & $€ 233 / \mathrm{ha}$ \\
\hline
\end{tabular}

Notes: All prices, support payments and costs are from the year 2006. The price of nitrogen is calculated on the basis of a compound NPK fertilizer.

Table A.2. Sensitivity analysis of social optimum: transportation costs (TC -20\%), climate benefit estimates $B$, nutrient runoff damage estimate $D$ and the socially optimal nitrogen use (average in bold, range in parentheses) and extensive margin in comparison to green set aside.

\begin{tabular}{|c|c|c|c|c|c|c|}
\hline & Baseline & $\begin{array}{l}B=10 ; \\
D=1.6\end{array}$ & $\begin{array}{l}B=30 ; \\
D=1.6\end{array}$ & $\begin{array}{l}B=10 ; \\
D=2.4\end{array}$ & $\begin{array}{l}B=20 ; \\
D=2.4\end{array}$ & TC -20\% \\
\hline $\begin{array}{c}\text { Nitrogen } \\
\text { use, } \mathrm{kg} / \mathrm{ha}\end{array}$ & $\begin{array}{c}\mathbf{5 6 . 3} \\
(49.9-67.4)\end{array}$ & $\begin{array}{c}\mathbf{4 6 . 9} \\
(41.6-52.3)\end{array}$ & $\begin{array}{c}\mathbf{6 7 . 6} \\
(60.1-78.8)\end{array}$ & $\begin{array}{c}\mathbf{4 5 . 1} \\
(39.9-50.4)\end{array}$ & $\begin{array}{c}\mathbf{5 4 . 7} \\
(48.1-65.2)\end{array}$ & $\begin{array}{c}\mathbf{5 6 . 2} \\
(48.4-63.0)\end{array}$ \\
\hline $\begin{array}{c}\text { Extensive } \\
\text { margin }\end{array}$ & 70 & 10 & 100 & 10 & 70 & 90 \\
\hline
\end{tabular}




\section{Appendix 2. Reed canary grass and current policy regime in Finland}

This Appendix describes the details of the current actual production of reed canary grass and oats in Finland. The private profits from cultivation were defined in equation (11) of the text. The location-specific fertilizer intensities and production per hectare are given in Table A.3.

Table A.3. Current policy: fertiliser use, crop production and profits under oats and reed canary grass cultivation.

\begin{tabular}{|c|c|c|c|c|c|c|}
\hline \multirow{2}{*}{$\begin{array}{c}\text { Location, } \\
k\end{array}$} & \multicolumn{3}{|c|}{ Reed canary grass } & \multicolumn{3}{c|}{ Oats } \\
\cline { 2 - 7 } & $\begin{array}{c}\text { N- use, } \\
\mathrm{kg} / \mathrm{ha}\end{array}$ & $\begin{array}{c}\text { Production, } \\
\mathrm{kg} / \mathrm{ha}\end{array}$ & $\begin{array}{c}\text { Profits, } \\
€ / \mathrm{ha}\end{array}$ & $\begin{array}{c}\mathrm{N}-\mathrm{use}, \\
\mathrm{kg} / \mathrm{ha}\end{array}$ & $\begin{array}{c}\text { Production, } \\
\mathrm{kg} / \mathrm{h}\end{array}$ & $\begin{array}{c}\text { Profits, } \\
€ / \mathrm{ha}\end{array}$ \\
\hline 0 & 48.0 & 5547 & 330.0 & 80.2 & 3135 & 267.9 \\
\hline 10 & 34.3 & 4895 & 305.9 & 79.2 & 3125 & 262.9 \\
\hline 20 & 30.4 & 4675 & 300.6 & 79.0 & 3122 & 261.6 \\
\hline 30 & 26.4 & 4430 & 295.8 & 78.8 & 3120 & 260.3 \\
\hline 40 & 22.2 & 4157 & 291.5 & 78.5 & 3117 & 259.1 \\
\hline 50 & 17.9 & 3849 & 287.6 & 78.3 & 3114 & 257.8 \\
\hline 60 & 13.5 & 3501 & 284.1 & 78.0 & 3112 & 256.6 \\
\hline 70 & 8.8 & 3100 & 281.1 & 77.8 & 3109 & 255.3 \\
\hline 80 & 3.9 & 2635 & 242.1 & 77.6 & 3107 & 254.1 \\
\hline 90 & 0.0 & 2238 & 240.0 & 77.3 & 3104 & 252.8 \\
\hline 100 & 0.0 & 2238 & 238.3 & 77.1 & 3101 & 251.6 \\
\hline
\end{tabular}

In Table A.3, the profits for reed canary grass dominate in the neighborhood of the power plant but from location $80 \mathrm{~km}$ onwards oats becomes more profitable. The associated nutrient runoff and climate benefits were collected in Table 3 of the text.

We examined how the private profitability of reed canary grass cultivation depends on exogenous parameters under the current policy regime. The results are described in Figure A.1; it shows the effects of a $20 \%$ reduction in transportation costs and a $20 \%$ increase in the price of reed canary grass paid by the power plant. Both increase the profitability of reed canary grass in comparison to the baseline. The higher output price provides higher profits than lower transportation costs in every location. However, the difference diminishes in distance as can been seen from the figure.

We also examined how the extensive margin changes if the alternative crop is green set aside instead of oats. The present value of profits from green set aside under the current agricultural support system is $€ 185.2$ /ha in every location. Thus, from profits reported in 
Table A.3 we find that the private profitability of green set aside is always inferior to both reed canary grass and oats under the current policy regime.

Figure A.1. Profits (€/ha) for reed canary grass under current policy (CR), under reduced of transportation costs (TC-20\%) and increased output price (Price $+20 \%)$.

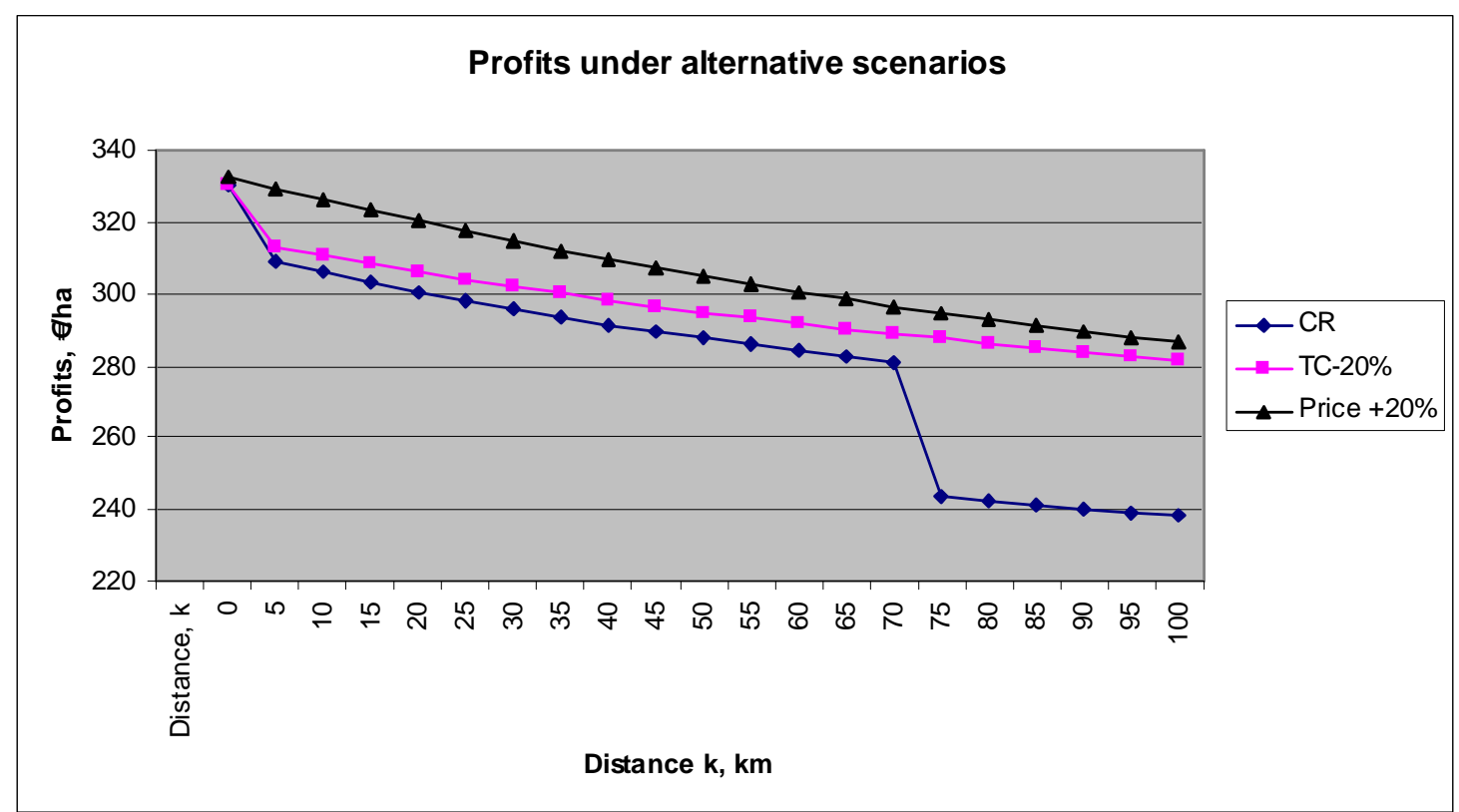


Discussion Papers:

No.

1. Jussi Lankoski, Markku Ollikainen \& Pekka Uusitalo (2004): No-till technology: benefits to farmers and the environment?" Environmental Economics.

2. Stefan Bäckman \& Alfons Oude Lansink (2004): Crop and soil specific mineral efficiency and productivity in Finland. Production Economics and Farm Management.

3. Antti lho (2004): Cost-effective reduction of phosphorus runoff from agriculture: a numerical analysis. Environmental Economics.

4. Jussi Lankoski, Erik Lichtenberg \& Markku Ollikainen (2004): Performance of alternative policies in addressing environmental dimensions of multifunctionality. Environmental Economics.

5. Kyösti Arovuori \& Jukka Kola (2004): Experts' opinions on policies and measures for multifunctional agriculture. Agricultural Policy.

6. Erikki Koskela, Markku Ollikainen \& Timo Pukkala (2004): Biodiversity policies in commercial boreal forests: optimal design of subsidy and tax combinations. Environmental Economics.

7. Lone Grønbæk Kronbak \& Marko Lindroos (2005): Sharing rules and stability in coalition games with externalities: the case of the Baltic Sea cod fishery. Environmental Economics.

8. Nina Hyytiä \& Jukka Kola (2005): Citizens' attitudes towards multifunctional agriculture. Agricultural Policy.

9. H. Dahlbo, M. Ollikainen, S. Peltola, T. Myllymaa \& M. Melanen (2005). Combining ecological and economic assessment of waste management options - case newspaper. Environmental Economics.

10. Aleksandar Shivarov, Soile Kulmala \& Marko Lindroos (2005). Fisheries Management Costs: The Case of Baltic Salmon Fishery. Environmental Economics.

11. Soile Kulmala, Hanna Peltomäki, Marko Lindroos, Sakari Kuikka \& Pirkko Söderkultalahti (2005). Individual Transferable Quotas in the Baltic Sea Herring Fishery: a Socio-bioeconomic Analysis. Environmental Economics.

12. Hanna-Mari Ahonen \& Kari Hämekoski (2005). Transaction costs under the Finnish CDM/JI Pilot Programme. Environmental Economics.

13. Chen Quizhen \& John Sumelius (2006). Comparative Study on Chinese and Finnish Experts' Opinion of Multifunctional Agriculture. Agricultural Economics.

14. Hervé Guyomard, Jussi Lankoski \& Markku Ollikainen (2006). Impacts of Agri-environmental Policies on Land Allocation and Land Prices. Environmental Economics.

15. Kyösti Arovuori \& Jukka Kola (2006). Farmers' choice on multifunctionality targeted policy measures. Agricultural Economics.

16. Seppo Vehkamäki \& Stefan Bäckman (2006). Evaluation of economic activities and poverty in the region close to the National Park of Río Abiseo in Peru. 